How Not to Be Eaten 



\title{
How Not to Be Eaten \\ The Insects Fight Back
}

\author{
Gilbert Waldbauer
}

With illustrations by fames Nardi

\section{무}

UNIVERSITY OF CALIFORNIA PRESS

Berkeley Los Angeles London 
University of California Press, one of the most distinguished university presses in the United States, enriches lives around the world by advancing scholarship in the humanities, social sciences, and natural sciences. Its activities are supported by the UC Press Foundation and by philanthropic contributions from individuals and institutions. For more information, visit www.ucpress.edu.

University of California Press

Berkeley and Los Angeles, California

University of California Press, Ltd.

London, England

(C) 2012 by Gilbert Waldbauer

Library of Congress Cataloging-in-Publication Data

Waldbauer, Gilbert.

How not to be eaten : the insects fight back / Gilbert Waldbauer ; with illustrations by James Nardi.

p. $\mathrm{cm}$.

Includes bibliographical references and index.

ISBN 978-0-520-26912-5 (cloth : alk. paper)

I. Insects-Defenses. 2. Insects-Predators of.

I. Title.

QL496.W336 2012

$595.7-\mathrm{dc} 23$

2011024488

Manufactured in the United States of America

$\begin{array}{llllllllll}21 & 20 & \text { I9 } & \text { I8 } & \text { I7 } & \text { I6 } & \text { I5 } & \text { I4 } & \text { I3 } & \text { I2 }\end{array}$

I0 $\quad 9 \begin{array}{lllllllll}8 & 7 & 6 & 5 & 4 & 3 & 2 & \text { I }\end{array}$

In keeping with a commitment to support

environmentally responsible and sustainable printing practices, UC Press has printed this book on Rolland Enviroroo, a Io०\% post-consumer fiber paper that is FSC certified, deinked, processed chlorine-free, and manufactured with renewable biogas energy. It is acid-free and EcoLogo certified. 
To Nancy Clemente

Dear friend and the best and most helpful

editor I have known 
